\title{
INCREASE OF FORWARDING PRODUCTIVITY AND REDUCTION OF TREE DAMAGES IN THINNING BY USE OF LOADING GRAPPLE WITH TILT FUNCTION
}

\author{
Santa Kaleja, Guna Petaja, Agris Zimelis, Kalvis Puzuls \\ Latvian State Forest Research Institute "Silava", Latvia \\ santa.kaleja@silava.lv, guna.petaja@silava.lv, agris.zimelis@silava.lv, kalvis.puzuls@silava.lv
}

\begin{abstract}
The aim of the study is to compare the forwarder grapple with a tilt function (tilt grapple) and the standard forwarder grapple, as well as to evaluate advantages and disadvantages of these grapples in thinning. Trials are conducted in 4 coniferous stands in North Western part of Latvia in state forests managed by the Joint stock company "Latvia State forests" (LSF). Two working methods are compared in the study. In the first method the forwarder is equipped with a grapple with the tilt mechanism and in the second method the standard grapple is used. Both methods are tested in the same stands. John Deere $810 \mathrm{D}$ forwarder is used as a base machine. Forwarding is carried out by two operators with similar work experience in thinnings, however, with no experience with tilt grapples, and each operator performed with both work methods. A time study is carried out during the trials, the amount of extracted timber is accounted and damages of remaining trees are estimated. According to the study results consumption of productive work time to transport $1 \mathrm{~m}^{3}$ of logs to roadside is by $3 \%$ smaller, if the tilt grapple is used, however, the difference is not significant. The impact of the operator on productivity is not statistically significant, too. According to the results of the study, the forwarding cost under conditions typical to the trials is $5.9 \mathrm{EUR} \cdot \mathrm{m}^{-3}$, if tilt grapple is used, and $7.4 \mathrm{EUR} \cdot \mathrm{m}^{-3}$, if the standard grapple is used. The amount of mechanical damages of remaining trees is smaller by $21 \%$ in areas where tilt grapple is used. The total number of damaged trees in control sites (forwarding with standard grapple) conforms with average data in forests managed by LSF.
\end{abstract}

Keywords: John Deere 810 D, forwarding, productivity, tilt grapple, tree damages.

\section{Introduction}

According to the information collected by LSF, the average productivity of forwarding in thinnings in the first seven months of 2017 were $8.6 \mathrm{~m}^{3}$ per engine hour (the average forwarding distance $-0.6 \mathrm{~km}$ ) [1]. In earlier trials with standard grapple the average productivity of John Deere $810 \mathrm{E}$ forwarder was $6.2 \mathrm{~m}^{3}$ per engine hour (the average hauling distance $0.8 \mathrm{~km}$ ), and the average productivity of Logbear F4000 forwarder was $5.6 \mathrm{~m}^{3}$ per engine hour (the average hauling distance $0.3 \mathrm{~km})[2-4]$.

The time consumed for loading and unloading operations significantly affects the productivity of forwarding. Studies carried out so far show that $43 \%$ (Logbear F4000) - 50 \% (John Deere 810 E) of productive working time on average is consumed for loading and unloading $1 \mathrm{~m}^{3}$ of logs [2;3].

There is a significant focus on minimizing damage to soil and remaining trees in the stand during thinning [5].While loading with the standard grapple without tilt function the operator can turn a bundle of logs in the horizontal plane, in order to move it from assortment piles in a stand to a log bunk. One of solutions to improve productivity of a forwarder and maintain quality of the stand is to equip the grapple with a tilting mechanism. The tilt mechanism ensures that the bundle of logs is not only turned in a horizontal plane, but also lifted in a vertical plane at the angle of $45^{\circ}$. Tilt mechanism is intended to be mounted on the hydraulic system between the grapple and rotator [6;7].

Buckets and grapples equipped with the tilt mechanism are widely used in construction works, using an excavator as the base machine, but their advantages have been studied in forestry as well [8]. Tilt mechanism, which is suitable for forwarders, is offered in the market by several producers, including Swedish company Sit Right AB [9].

Results of studies conducted in Finland and Sweden showed that productivity of a forwarder equipped with the tilt grapple was higher by $7-10 \%$ comparing with the standard grapple. It also provides more comfortable work conditions to the operator [10].

In a study conducted in Sweden in 2013 the BioTassu tilt mechanism manufactured by Sit Right $\mathrm{AB}$ was tested. The aim of the study was to investigate, if there are differences in productivity between use of the standard grapple and the tilt grapple in thinnings of stands with various density. It was observed in the study that in stands, where the number of trees does not exceed 1000 per hectare, use of the standard grapple increases the productivity by $6.6 \%$ in comparison to the tilt grapple. Increase of productivity can be explained with the ability to pick larger bundles of logs in a single 
grip, consequently saving the time for loading. In stands, where the number of trees does not exceed 1500 and 2000 per hectare, the productivity is still higher, if the standard grapple is used, accordingly $1 \%$ and $13.8 \%$; however, the number of damaged trees was significantly bigger in the areas, where the standard grapple was used (trees were damaged in $25 \%$ of work cycles). When the tilt grapple was used, the trees were damaged only in $7.5 \%$ of work cycles, respectively use of the tilt grapple results in reduction of mechanical damages by $17 \%$. Trials conducted in Sweden have shown that usage of the tilting grapple does not increase the fuel consumption of the forwarder and does not cause additional vibrations, which would worsen the working conditions for the operators [11].

Mechanical damages of remaining trees by forest machines reduce both, quality of timber and the income projections in regenerative felling. The damages also facilitate fungal infections, which lead to wood degradation [12]. Following to the infection, the decay invades the central part of the tree stem and a heart rot is formed. Several studies have been conducted to investigate the aspects of damages in thinnings. In a study conducted in Sweden in spruce stands it was found that more tree damages occurred to trees next to strip roads and stem damages negatively correlated with the width of the strip roads. In a study carried out in Canada there were also more damages on the trees that are located along the forwarder trails, but wounds on those trees were not significantly larger [13].

The aim of the study is to compare the tilt grapple and the standard grapple in forwarding of logs in commercial thinning by evaluation of advantages and disadvantages of these two types of loader grapples.

\section{Materials and methods}

The study is implemented in middle age forest stands on drained mineral soils, where the dominant species (at least $70 \%$ ) are conifers. In total four conifer stands were selected with the total area of 10.5 ha. Characteristics of the stands are provided in Table 1. John Deere $810 \mathrm{D}$ forwarder is used in the trials; technical specifications are provided in Table 2.

Table 1

Characteristics of forest stand

\begin{tabular}{|c|c|c|c|c|c|c|c|}
\hline \multicolumn{2}{|c|}{ LKS92 coordinates } & \multirow{2}{*}{$\begin{array}{c}\text { Area, } \\
\text { ha }\end{array}$} & \multirow{2}{*}{\begin{tabular}{|c|} 
Growing \\
stock, $\mathbf{m}^{3}$ ha'
\end{tabular}} & \multirow{2}{*}{$\begin{array}{l}\text { Dominant } \\
\text { species }\end{array}$} & \multirow{2}{*}{$\begin{array}{c}\text { Height } \\
\text { of trees, } \\
\text { m }\end{array}$} & \multirow{2}{*}{$\begin{array}{l}\text { Diameter } \\
\text { at breast } \\
\text { height, } \mathrm{cm}\end{array}$} & \multirow{2}{*}{$\begin{array}{l}\text { Age in } \\
\text { years }\end{array}$} \\
\hline $\mathbf{X}$ & $\mathbf{Y}$ & & & & & & \\
\hline 375920 & 349772 & 2.9 & 286 & Norway spruce & 20 & 20 & 42 \\
\hline 375735 & 34972 & 6. & 300 & & 13 & 13 & 36 \\
\hline 375643 & 3495 & 0 . & 40 & & 21 & 20 & 50 \\
\hline 376063 & 349835 & 0.6 & 387 & Norway spruce & 22 & 21 & 55 \\
\hline
\end{tabular}

Technical specifications of John Deere 810 D forwarder [10]

\begin{tabular}{|c|c|c|}
\hline Features & Unit & Value \\
\hline Unladen weight & $\mathrm{kg}$ & 10970 \\
\hline Engine & $\mathrm{hp}$ & 115 \\
\hline Maximum speed & $\mathrm{km} \cdot \mathrm{h}^{-1}$ & 23 \\
\hline Load area & $\mathrm{m}^{2}$ & 3.4 \\
\hline Length & $\mathrm{m}$ & 8.0 \\
\hline Width & $\mathrm{m}$ & 2.5 \\
\hline Boom length & $\mathrm{m}$ & 9.8 \\
\hline
\end{tabular}

The forwarder was equipped with the tilt grapple Bio Tassu. The weight of the tilt mechanism is $66 \mathrm{~kg}$, maximum lifting capacity -3.5 tonnes, it can lift up to $0.28 \mathrm{~m}^{3}$ in a single grip. The tilt mechanism is suitable for small and middle class forwarders. The price of the tilt mechanism is about 3000 EUR.

Time studies of forwarding operations are carried out using a field PC Allegro CX, equipped with time accounting software SDI. Additionally to time accounting, the index number of strip roads and 
other explanatory notes are recorded during the studies. A forwarding cycle is divided into 16 work elements. Description of each element is given in Table 3.

Table 3

Description of work operations

\begin{tabular}{|c|c|c|}
\hline No & Work elements & Description \\
\hline 1. & Drive in & Drive in stand \\
\hline 2. & Drive out & Driving out of the felling site \\
\hline 3. & Reach & Reach for an logs when loading in \\
\hline 4. & Grip & Gripping the logs when loading in \\
\hline 5. & Load in & Loading in the logs in bunk \\
\hline 6. & Tilt function & $\begin{array}{l}\text { A bundle of logs is turned in the horizontal plane or tilted } \\
\text { and turned at a } 45^{\circ} \text { angle in the vertical plane }\end{array}$ \\
\hline 7. & Arrange & Arrange logs in bunk \\
\hline 8. & Drive in stand & Movement of the forwarder in felling site, when loading in \\
\hline 9. & Strip road & Putting residues into a strip road \\
\hline 10. & Other operations & $\begin{array}{l}\text { Other operations related to work (picking up assortments } \\
\text { that have fallen out, adjusting logs etc.) }\end{array}$ \\
\hline 11. & $\begin{array}{l}\text { Reach when } \\
\text { loading out }\end{array}$ & Reach for logs when loading out \\
\hline 12. & $\begin{array}{l}\text { Grip when } \\
\text { loading out }\end{array}$ & Gripping logs when loading out \\
\hline 13. & Load out & Loading out logs from the bunk \\
\hline 14. & $\begin{array}{l}\text { Arrange landing } \\
\text { area }\end{array}$ & Arranging logs in landing area \\
\hline 15. & $\begin{array}{l}\text { Drive in landing } \\
\text { area }\end{array}$ & Driving between piles when loading out in landing area \\
\hline 16. & $\begin{array}{l}\text { Other operations } \\
\text { unrelated to } \\
\text { direct work }\end{array}$ & Activities unrelated to work (phone calls, smoking, etc.) \\
\hline
\end{tabular}

Two working methods are compared during trials:

1. Forwarder is equipped with a grapple with the tilt function and operators use this function on demand;

2. Standard grapple is mounted and logs are loaded in horizontal position only.

Trials with both methods were conducted in the same felling sites. The trials were conducted from 09.10.2017 till 13.10.2017. The average daily temperature during the trials was between 7.4 and $11.6^{\circ} \mathrm{C}$. There was strong $(10 \mathrm{~mm}$ daily) and significant $(6-10 \mathrm{~mm}$ daily) rainfall during the first days of the trials and it was raining every day with varying intensity. There was moderate wind (9.7$\left.13.9 \mathrm{~m} \cdot \mathrm{s}^{-1}\right)$. However, according to the operators' opinion the weather did not significantly affect the productivity of forwarding.

Damages to remaining trees are accounted across the strip-roads, respectively all damages are accounted. Mechanical damages are marked after harvesting to separate forwarding related damages. The sample plot method is used to measure stand conditions before and after thinning; diameter at breast height of all trees thicker than $4 \mathrm{~cm}$ and the height of sample trees are measured in sample plots. Distribution of sample plots in stands is systematic. Size of the circular sample plots before thinning is $200 \mathrm{~m}^{2}$; after thinning rectangular plots with area of $400 \mathrm{~m}^{2}(10 \mathrm{x} 40 \mathrm{~m})$. Three types of damages are accounted: stem damages up to $0.5 \mathrm{~m}$ above ground, stem damages above $0.5 \mathrm{~m}$ from the ground and root damages. Bark bruise of both stem and root (root is located no further than $70 \mathrm{~cm}$ from the tree and the diameter is at least $2 \mathrm{~cm}$ ) is counted as damage, if the area of the revealed damage exceeds $10 \mathrm{~cm}^{2}$. 


\section{Results}

\section{Comparison of forwarding productivity between two working methods}

In total comprehensive time studies are carried out during forwarding of $470 \mathrm{~m}^{3}$ of logs or 72 loads (average load size $-6.5 \mathrm{~m}^{3}$ ) using both work methods. The second work method (using the standard grapple) is applied, when $55 \%$ of logs are forwarded.

On average the proportion of productive time consumption per load, using the tilt grapple and the standard grapple, accordingly, is $95 \%$ and $98 \%$ from the total work time. No significant difference is found. On average forwarding of 1 load takes 32 min of productive work time. Using of the second method (standard grapple) results in $2.1 \%$ less productive work time per load (average load size $5.7 \mathrm{~m}^{3}$ ) in comparison to the first method with the tilt grapple (average load $7.4 \mathrm{~m}^{3}$ ). Difference in productivity calculated as time spent per load is not significant. The reason for smaller loads in the second method (with the standard grapple) is not explained during the study; volume of loads is determined by the operators. In future studies visual inspection should be replaced by weighing of loads to obtain more accurate data.

In calculation to extracted volume the average productivity in the trial is $12 \mathrm{~m}^{3}$ per productive work hour. Forwarder, equipped with the tilt grapple in trials demonstrates higher productivity (by $21 \%$ ) in comparison to operations with the standard grapple, even if the average load is considerably smaller. The average productivity figures for the tilt grapple are $13.5 \mathrm{~m}^{3}$ per productive hour comparing with $10.7 \mathrm{~m}^{3}$ per productive hour for the forwarder equipped with the standard grapple. According to the study results productivity of the forwarder with the tilt grapple during loading is $21 \mathrm{~m}^{3}$ per productive hour and during loading out $-78 \mathrm{~m}^{3}$ per productive hour; in both cases the productivity is considerably higher in comparison to the standard grapple, respectively, by $19 \%$ and $20 \%$. However, the results are highly uncertain, particularly due to visual inspection based estimation of load volumes.

On average forwarding of $1 \mathrm{~m}^{3}$ of logs takes $5.0 \mathrm{~min}$ of productive work time in the study conditions. Time saving due to use of the tilt grapple is $21 \%\left(4.4 \mathrm{~min} . \mathrm{m}^{3}\right.$ in average) according to the study results. However, statistically significant difference of the main productivity indicators is not found between both methods, accordingly $p=0.097>0.05$ and $p=0.059>0.05$.

The first operator forwarded $59 \%$ of the total volume or $278 \mathrm{~m}^{3}$, from which $54 \%\left(150 \mathrm{~m}^{3}\right)$ were forwarded using the second method and $46 \%$ or $128 \mathrm{~m}^{3}$ of $\operatorname{logs}-$ using the first method. The second operator forwarded $193 \mathrm{~m}^{3}$ of logs in total, from which $68 \%\left(130 \mathrm{~m}^{3}\right)$ are forwarded using the first method and $32 \%$ or $62 \mathrm{~m}^{3}$ of logs are forwarded using the second method. The average load of the first operator according to his own estimate is smaller by $8 \%\left(6.3 \mathrm{~m}^{3}\right)$, comparing with the second operator $\left(6.9 \mathrm{~m}^{3}\right)$. The productivity of the first operator regardless of the method is higher by $2 \%$ in comparison to the second operator. The difference is not significant.

\section{Prime cost of forwarding}

In order to calculate the prime cost of forwarding, the average productivity and the average load size of the forwarder are used. It was assumed that the average hauling distance is $400 \mathrm{~m}$ and the average driving speed of the forwarder is $52 \mathrm{~m} \cdot \mathrm{min}^{-1}$. The average productivity indicators of John Deere $810 \mathrm{D}$ forwarder with and without additional equipment are given in Table 4 . It is assumed in the calculations that operators are working in 2 shifts and the length of each shift is $8 \mathrm{~h}$.

Table 4

Productivity indicators assumed in calculations

\begin{tabular}{|c|c|c|c|}
\hline Method & Load size, $\mathbf{m}^{3}$ & $\begin{array}{l}\text { Productive time ,load } \\
\text { in”, min. load }\end{array}$ & $\begin{array}{l}\text { Productive time ,,load } \\
\text { out", min. load }^{-1}\end{array}$ \\
\hline Grapple with the tilt function & 7.4 & 21.0 & 6.0 \\
\hline Standard grapple & 5.7 & 19.7 & 5.5 \\
\hline
\end{tabular}

Prime cost of forwarding with the forwarder equipped with the tilt grapple is considerably smaller (Table 5) according to the study results, mainly because of bigger loads in this method. Additional cost of the tilt mechanism is compensated by increased productivity. Use of the tilt grapple have limited 
impact on prime hourly cost of the forwarder; in both methods it is 50 EUR. However, there are limited data available on the life-time of tilt grapples, the assumption that the tilt mechanism can operate as long as the grapple may be too optimistic.

Fuel consumption to transport $1 \mathrm{~m}^{3}$ of $\operatorname{logs}$ to $400 \mathrm{~m}$ distance is 1.41 with the standard grapple and 1.11 with the tilt grapple. The difference in fuel consumption is mainly due to different load sizes in both methods.

Table 5

Prime cost analysis of forwarding

\begin{tabular}{|c|c|c|}
\hline Parameter & Forwarder with tilt grapple & $\begin{array}{c}\text { Forwarder with standard } \\
\text { grapple }\end{array}$ \\
\hline Investment & EUR 35902 & EUR 34101 \\
\hline Personnel costs & EUR 62637 & EUR 62637 \\
\hline Operational costs & EUR 60385 & EUR 58826 \\
\hline Planned income & EUR 7946 & EUR 7778 \\
\hline Total, EUR & EUR 166869 & EUR 163341 \\
\hline $\begin{array}{c}\text { Stem logs with bark, } \text { m }^{\mathbf{3}} \text { per } \\
\text { productive hour }\end{array}$ & 10.4 & 24400 \\
\hline Annually produced logs, $\mathrm{m}^{\mathbf{3}}$ & 31335 & EUR 7.43 \\
\hline Prime cost of forwarding, EUR $\mathrm{m}^{\mathbf{3}}$ & EUR 5.91 \\
\hline
\end{tabular}

\section{Damages to remaining trees}

The number of trees damaged after harvesting does not differ significantly between areas later extracted by the forwarder equipped with standard and tilt grip. After forwarding the number of mechanically damaged remaining trees is significantly smaller if the tilt grapple is used $-2.9 \%$ in comparison to $3.6 \%$, if the standard grapple is used, respectively use of the tilt grapple results in reduction of the number of damaged trees by $21 \%$.

\section{Conclusions}

1. Use of the tilt grapple does not have an impact on the share of productive work time, respectively, during the study it did not expand the service time significantly.

2. Average load size during the study was considerably bigger $\left(7.4 \mathrm{~m}^{3}\right.$ in comparison to $\left.5.7 \mathrm{~m}^{3}\right)$, when the tilt grapple was used. Explanation for this phenomenon was not found during the study. Further research with instrumental measurement of loads is necessary to evaluate, if this result is systematic and depends on the grapple type.

3. Productivity of the forwarder equipped with the tilt grapple in the study was higher by $21 \%$ in comparison to the forwarder with the standard grapple, however no significant differences were found.

4. No significant difference is found between the productivity of the operators, which means that both operators easily adapted to the tilt grapple and were able to use the benefits provided by the new work method.

5. Forwarding cost is considerably smaller, using the tilt grapple. However, the main reason for such result is considerably bigger loads, when the tilt grapple is used.

6. Use of the tilt grapple has a significant impact on damages to remaining trees (from $3.6 \%$ to $2.9 \%$ ), which is the main approved advantage of the tilt grapple. This finding approves the assumption that tilt grapples should be recommended for use in thinning.

\section{References}

[1] JSC "Latvia state forests," Forvardera darba ražīgums (Forwarder productivity), 2018 (in Latvian).

[2] RitchieSpecs, John Deere 810D Forwarder, 2018.

[3] Kaleja S., Zimelis A., Lazdins A., Johansson P.O., Comparison of productivity of Kranman Bison 10000 forwarder in stands harvested with harvester and chainsaw. Proceedings of the 8th 
International Scientific Conference Rural Development 2017, November 23-24, 2017, Kaunas, Lithuania, pp. 318-323.

[4] Prindulis U., Lazdinš A., Kaleja S. Impact of biomass extraction method on damage to remaining trees in mechanized thinning of deciduous stands. Proceedings of Annual $21^{\text {st }}$ International Scientific Conference "Research for Rural Development 2015", May 13-15, 2015, Jelgava, pp. 74-80.

[5] Lazdinš A., Prindulis U., Kalēja S., Daugaviete M., Zimelis A. Productivity of Vimek 404 T5 harvester and Vimek 610 forwarder in early thinning. Agronomy Research, vol. 14, 2016, pp. 475-484.

[6] Zimelis A., Lazdins A., Kaleja S., Spalva G., Rozitis G. Productivity of harvester Vimek 404 T5 in forest thinning in Latvia. Proceedings of Logging Industry: Problems And Solutions Materials of International Scientific-Technical Conference in Memory of Professor Alexander Fedorenchik, April 26-18, 2017, Minsk, Belarus, pp. 36-39.

[7] Zimelis A., Lazdiņš A., Spalva G. Comparison of productivity of Vimek harvester in birch plantation and young coniferous stands. Proceedings of Annual 23rd International Scientific Conference "Research for Rural Development 2017", May 17-19, 2017, Jelgava, Latvia, pp. 107-112.

[8] Petaja G., Muižnieks E., Kalēja S. Efficiency of Vimek 610.2 forwarder and its impact on soil in forest thinning, Proceedings of the 8th International Scientific Conference Rural Development 2017, November 23-24, 2017, Kaunas, Lithuania, pp. 740-745.

[9] Dala-Gripen, Biotassu/Griptilt, (2018).

[10] Häggström C., Öhman M., Burström L., Nordfjell T., Lindroos O. Vibration Exposure in Forwarder Work: Effects of Work Element and Grapple Type, Croatian Journal of Forest Engineering, vol. 37, 2016, pp. 107-118.

[11] Nilsson G. Griptiltens effekt på skotarens produktivitet (Effects of grapple-tilt on forwarder productivity). Sveriges lantbruksuniversitet, Institutionen för skoglig resurshushållning, 2013 (in Swedish).

[12] Pohjankukka J., Riihimäki H., Nevalainen P., Pahikkala T., Ala-Ilomäki J., Hyvönen E., Varjo J., Heikkonen J. Predictability of boreal forest soil bearing capacity by machine learning, Journal of Terramechanics, vol. 68, 2016, pp. 1-8.

[13] Heitzman E., Grell A. Residual Tree Damage Along Forwarder Trails from Cut-to-Length Thinning in Maine Spruce Stands, Northern Journal of Applied Forestry, vol. 19, 2002, pp. 161-167. 